\title{
Getting to know the city: the construction of spatial knowledge in London in the 1930s
}

\author{
COLIN G. POOLEY* \\ Department of Geography, Lancaster University, Lancaster LA1 4YB
}

\begin{abstract}
This article explores the ways in which a young woman who migrated from Londonderry to London in the 1930s acquired and used spatial knowledge of the city. Using detailed diary evidence the article maps everyday action spaces, and examines themes such as the use of visual cues in the accumulation of spatial knowledge, the use of maps and signs, the influence of previous travel experiences and the organization of search and exploration strategies in the city.
\end{abstract}

When someone moves to a new town they necessarily acquire information about the place. Today there are many different ways to gain this knowledge: they may talk to friends, read guidebooks and magazines, download material from the web or watch relevant programmes on TV. The acquisition of such information both adds to the enjoyment of being in a new place, and aids the process of settling in to a new home. Knowledge of an urban area may help to choose a suitable home or school, to determine a journey to work, to establish a regular pattern of shopping and to develop links with facilities and the local community. This process of gaining spatial knowledge, that aids assimilation to a new environment, is usually taken for granted and is rarely examined in an historical context. However, it may fundamentally affect the ways in which someone uses the city, their interaction with neighbours and the environment and their overall quality of life. Limited knowledge may lead to isolation, restricted mobility and social exclusion. ${ }^{1}$

This article takes the theme of knowledge and the city and explores the ways in which a young woman who migrated from Londonderry (Northern Ireland) to London (England) in the late 1930s acquired and used knowledge of a city that she was visiting and living in for the first time. In doing so, the article explores two more specific questions: how

\footnotetext{
* Thanks to Mrs Rhona Ward for making the diaries available, allowing them to be copied and agreeing to be interviewed; to the ESRC for funding a research project on the longitudinal analysis of residential histories during which the diaries were initially identified; and to Dr Jean Turnbull who was Research Associate on the ESRC project.

${ }^{1}$ M. Rahman, G. Palmer and P. Kenway, Monitoring Poverty and Social Exclusion 2001 (York, 2001); D. Byrne, Social Exclusion (London, 1999).
} 
does a newly arrived migrant gain spatial knowledge of a large urban area; and how does the acquisition of spatial knowledge of the city influence an individual's everyday life and use of that urban space? Research for this article has developed from a large-scale project on migration in Britain in which, amongst other evidence, we collected a number of personal diaries and accounts of migration. ${ }^{2}$ One such diary provides evidence for this article. Material on the process of migration and the construction of identity has been published elsewhere, ${ }^{3}$ but the source has not been used previously to explore the themes addressed in this article.

\section{Context}

There is a long tradition of studies of spatial cognition in psychology, geography and urban planning, but little that has systematically applied these concepts in an historical context. Perhaps the seminal text from a geographical perspective is Kevin Lynch's The Image of the City. ${ }^{4}$ In this influential work, Lynch focused on the interaction between environmental cues and spatial knowledge, arguing that the physical structure of the city the way in which it is designed and ordered - influences our ability to find our way around an urban area. In his introduction Lynch summarizes the importance of adequate spatial knowledge:

To become completely lost is perhaps a rather rare experience for most people in the modern city. We are supported by the presence of others and by special wayfinding devices: maps, street numbers, route signs, bus placards. But let the mishap of disorientation occur, and the sense of anxiety and even terror that accompanies it reveals to us how closely it is linked to our sense of balance and well-being. ${ }^{5}$

To some degree such work drew on the tradition of urban ecology, and the associated concern with neighbourhood and community interaction, which was most clearly represented by the work of American sociologists in Chicago from the 1920s. ${ }^{6}$ But Lynch focused attention much more clearly on the interaction between the individual and urban design and avoided the ecological assumptions of Park and his associates. The theme of cognitive mapping - the way in which we collect, store and use spatial images - became rather fashionable in behavioural geography in the 1970s, focusing especially on the concept of 'Mental Maps" ${ }^{7}$ and summarized most fully in a volume by Downs and Stea that focuses on the ways in

${ }^{2}$ C. Pooley and J. Turnbull, Migration and Mobility in Britain since the Eighteenth Century (London, 1998).

3 C. Pooley, 'From Londonderry to London: identity and sense of place for a Protestant Northern Irish woman in the 1930s', Immigrants and Minorities, 18 (1999), 189-213.

${ }^{4} \mathrm{~K}$. Lynch, The Image of the City (Cambridge, MA, 1960).

${ }_{6}^{5}$ Ibid., p. 4.

6 R. Park and E. Burgess, The City (Chicago, 1925).

7 P. Gould and R. White, Mental Maps (Harmondsworth, 1974). 
which spatial images are learned, stored and used in everyday life. ${ }^{8}$ More recent writing by geographers has extended these themes, ${ }^{9}$ and has linked them to the cultural interpretation of the use of space and the interpretation of geographies of 'everyday life' ${ }^{10}$

Mobility within the city, and its meaning for everyday life, is also a key theme in Hagerstrand's 'time geography', developed in the 1960s and $1970 \mathrm{~s}^{11}$ and has been extended in more recent cultural studies that seek to ascribe meanings to urban life and to movement within the urban environment. ${ }^{12}$ The works of Lefebvre and Bourdieu have been especially influential. Lefebvre identified three key elements of urban space: spatial practice, or the ways in which space is organized and used; representations of space, conceived mainly by architects, planners and those in control of urban environments; and representational space, or the images and meanings associated with space by those who use it. ${ }^{13}$ Bourdieu's concept of 'habitus' focuses on the construction of meaning in everyday lifeworlds. Whilst 'habitus' is related to objective criteria such as class, gender and ethnicity, it is additionally concerned with values, cognitive structures and everyday practices including such things as dress, language, comportment and consumption. ${ }^{14}$ However, these studies often lack empirical historical evidence to substantiate their theoretical arguments. Material presented in this article may help to test some of the theoretical formulations. Such work can also be related to research in cognitive and developmental psychology that explores, much more scientifically than most research by geographers,

8 R. Downs and D. Stea, Maps in Minds: Reflections on Cognitive Mapping (London, 1977).

9 S. Aitken, 'Person-environment theories in contemporary perceptual and behavioural geography I: personality, attitudinal and spatial choice theories', Progress in Human Geography, 15 (1991), 179-63; S. Aitken, 'Person-environment theories in contemporary perceptual and behavioural geography II: the influence of ecological, environmental learning, society/structural, transactional and transformational theories', Progress in Human Geography, 16 (1992), 553-62; R. Golledge and R. Stimson, Spatial Behaviour: A Geographic Perspective (New York, 1997).

10 J. Eyles, 'The geography of everyday life', in D. Gregory and R. Walford (eds.), Horizons in Human Geography (London, 1989), 102-17; A. Madanipour, Design of Urban Space: An Enquiry into Socio-Spatial Process (Chichester, 1996); L. Holloway and P. Hubbard, People and Place: The Extraordinary Geographies of Everyday Life (Harlow, 2001).

11 T. Hagerstrand, 'Space, time and human conditions', in A. Karlqvist, L. Lundqvist and F. Snickars (eds.), Dynamic Allocation of Urban Space (Farnborough, 1975), 3-14; T. Carlstein, D. Parkes and N. Thrift (eds.), Timing Space and Spacing Time, vol. II: Human Activity and Time Geography (London, 1978).

12 P. Bourdieu, Distinctions: A Social Critique of the Judgement of Taste (London, 1984); M. de Certeau, The Practice of Everyday Life (Berkley, CA, 1984); D. Harvey, The Condition of Postmodernity (Oxford, 1989); H. Lefebvre, The Production of Space (Oxford, 1991); J. Urry, Sociology beyond Societies: Mobilities for the Twenty-First Century (London 2000); M. Bull, Sounding out the City: Personal Stereos and the Management of Everyday Life (Oxford, 2000); C. Pooley, 'Patterns on the ground: urban form, residential structure and the social construction of space', in M. Daunton (ed.), The Cambridge Urban History of Britain, vol. III: 1840-1950 (Cambridge, 2000).

13 Lefebvre, The Production of Space.

14 Bourdieu, Distinctions. 
how people (and especially children) ${ }^{15}$ acquire, store and use knowledge, including spatial information. Recent research in this area has focused on issues such as gender, age and class variations in spatial knowledge, and on the extent to which spatial knowledge is linked to an individual's wider travel experience. ${ }^{16}$ However, the relative importance of different factors that may influence spatial cognition appears to remain uncertain.

Drawing on this wide range of research it can be suggested that there are a number of key factors that may be explored in relation to the acquisition of spatial knowledge by a migrant newly arrived in a city. These include investigation of the impact that specific environmental cues have on the acquisition of spatial knowledge; assessment of the specific finding aids (maps, signs) that an individual utilizes in acquiring spatial knowledge; examination of the ways in which previous travel experiences influence the development of spatial knowledge in a new environment; analysis of the organization and structure of individual search and exploration strategies; and investigation of the extent to which the acquisition of knowledge of a city is a voluntary activity, or something forced on individuals by necessity? In this article, these issues are explored in a specific historical context: that of a young woman exploring London for the first time in the 1930s.

\section{The source}

Analysis presented in this article is based on one set of diaries principally covering the period 1937 to 1942 . They form an extraordinarily rich account of everyday life for a young woman who migrated from Londonderry (Northern Ireland) to London (England) and of her adjustment to life in the metropolis prior to and during the Second World War. The validity of the interpretation presented obviously depends on the reliability and content of the source, and there is a substantial literature on the interpretation of writing about the self in both the present and the past. However, most studies focus on the writings of a small and atypical elite group who were both literate and leisured, and often had a particular reason for putting their thoughts in writing. ${ }^{17}$ Historical geographers and others have

15 M. Matthews, Making Sense of Place: Children's Understanding of Large-Scale Environments (Hemel Hempstead, 1992).

16 L. Anooshian, 'Diversity within spatial cognition: strategies underlying spatial knowledge', Environment and Behaviour, 28 (1996), 471-93; J. Chiodo, 'Improving the cognitive development of students' mental maps of the world', Journal of Geography, 96 (1997), 15363; J. Dabbs, E. Chang, R. Strong and R. Milun, 'Spatial ability, navigational strategy and geographic knowledge among men and women', Ethology and Social Biology, 19 (1998), 89-98; M. Joshi, M. MacLean and C. Wakefield, 'Children's journey to school: spatial skills, knowledge and perceptions of the environment', British Journal of Developmental Psychology, 17 (1999), 125-39.

17 J. Morris, Versions of the Self: Studies in English Autobiography from John Bunyan to John Stuart Mill (London, 1966); L. Peterson, Victorian Autobiography: The Tradition of Self-Interpretation 
concentrated especially on the meaning of landscape in the past, expressed through the literature and art of the time, ${ }^{18}$ and on the genre of travel writing. ${ }^{19}$ Though revealing about one group of influential opinion, such studies tell little about the importance of place in the lives of ordinary people. The best glimpses into the everyday lives of relatively ordinary people come through rarely surviving diaries, autobiographies and life histories written at the time, though these too can only reflect the lives of a literate minority amongst the working class. ${ }^{20}$ As with accounts written by the rich and famous, we must also question why such accounts were kept, what the intended audience was and whether the writer was trying to convey a particular message. ${ }^{21}$ However, in comparison with autobiographies and other writing, the analysis of diaries has received very little critical attention. ${ }^{22}$ The diary on which this article is based begins to fill this gap.

The diarist (R) was born into a Protestant family in Londonderry in 1919, and in January 1938 she migrated alone from Londonderry to London to take work as a typist with the Inland Revenue, having taken the Civil Service typing exams in Northern Ireland. This article focuses especially on R's first few months in London, exploring her spatial search strategies when she first arrived in the city. The level of detail included in the diaries

(New Haven and London, 1986); J. Simons, Diaries and Journals of Literary Women from Fanny Burney to Virginia Woolf (London, 1990).

${ }^{18}$ D. Cosgrove and S. Daniels (eds.), The Iconography of Landscape: Essays on the Symbolic Representation, Design and Use of Past Environments (Cambridge, 1988); S. Daniels, Fields of Vision: Landscape, Imagery and National Identity in England and the United States (Cambridge, 1993); C. Withers, 'How Scotland came to know itself: geography, national identity and the making of a nation 1680-1790', Journal of Historical Geography, 21 (1995) 371-97.

19 D. Gregory, 'Between the book and the lamp: imaginative geographies of Egypt, 1849-50', Transactions of the Institute of British Geographers, n.s. 20 (1995), 29-57; C. McEwan, 'Paradise or pandemonium? West African landscapes in the travel accounts of Victorian women', Journal of Historical Geography, 22 (1996), 68-83.

20 J. Marshall (ed.), The Autobiography of William Stout of Lancaster, 1665-1772 (Manchester, 1967); J. Burnett (ed.), Useful Toil: Autobiographies of Working-Class People from the 1820s to the 1920s (London, 1974); A. Macfarlane (ed.), The Diary of Ralf Josselin 1616-83 (Oxford, 1976); J. Burnett (ed.), Destiny Obscure: Autobiographies of Childhood, Education and Family from the 1820s to the 1920s (London, 1982); D. Vincent (ed.), Bread, Knowledge and Freedom: A Study of Nineteenth Century Working Class Autobiography (London, 1981); A. Crocker and M. Kane (eds.), The Diaries of James Simmons, Article Maker of Haslemere, 1831-1868 (Oxshott, 1990); A. Crosby (ed.), The Family Records of Benjamin Shaw: Mechanic of Dent, Dolphinholme and Preston, 1772-1841 (Manchester, 1991).

21 E. Richards, 'Voices of British and Irish migrants in nineteenth-century Australia', in C. Pooley and I. Whyte (eds.), Migrants, Emigrants and Immigrants: A Social History of Migration (London, 1991), 19-41; C. Pooley and J. Turnbull, 'Changing home and workplace in Victorian London: the life of Henry Jaques, shirtmaker', Urban History, 24 (1997), 148-78.

22 A. Ponsonby, English Diaries: A Review of English Diaries from the Sixteenth to the Twentieth Century, with an Introduction on Diary Writing (London, 1923); R. Fothergill, Private Chronicles: A Study of English Diaries (London, 1974); A. Fleishman, Figures of Autobiography: The Language of Self-Writing in Victorian and Modern England (Berkeley, CA, 1983); W. Runyan, Life Histories and Psychobiography: Explorations in Theory and Method (Oxford, 1984); H. Henderson, The Victorian Self: Autobiography and Biblical Narrative (Ithaca, NY, 1989). 
between 1937 and 1942 is extraordinary, with 1938 alone covering four large handwritten volumes. They were clearly written up each evening, and record almost everything that she did during the day, including where she went, whom she was with, what food she ate (and how much it cost), what books she read, the films she saw and her thoughts, hopes and fears. In particular they provide a vivid insight into the process of migration, her feelings on leaving home and her adjustment to life and work in London.

It is probably not uncommon for a young woman to keep a personal diary, but these records are unusual in their detail and consistency over a prolonged period, in the fact that they have survived some 60 years and have been made available for historical analysis and in the degree to which they provide information on the process of migration and adjustment to life in London. The diaries were clearly written as a personal document, with no expectation that they would ever be read by anyone else and, as far as can be ascertained, factual information in the diaries is accurate. It is obviously important to remain critical of the source, but there is no evidence that the writer had any other motive than that of recording her everyday activities in a mostly matter-of-fact way. Additional information has been added from an extended interview with the diarist conducted in her own home in 1996, and this oral evidence has been used to probe some diary evidence in more detail. However, the oral responses are inevitably affected by R's later life in London, and by the influence of time on memory. ${ }^{23}$ In this article, most emphasis is given to the diary entries which record R's feelings about life in London when the diary was written (albeit filtered through her perceptions at that point in time), rather than her later reflections. There is not space to explore differences between the oral and written evidence in this article. All references to individuals have been anonymized in the following analysis, but everything else is reported as recorded in the diary or interview.

\section{Action space in London in the 1930s}

Before exploring search strategies and the acquisition of spatial knowledge in detail, it is useful to contextualize R's life in London. This can be done by exploring the action spaces through which $\mathrm{R}$ moved during her early life in the city, but first there is need to provide some brief background to the city. Although in the first half of the twentieth century London experienced a net loss of population, as those who were able to moved to expanding suburbs and satellite towns, ${ }^{24}$ there continued to be a substantial inflow of migrants to London from most parts of the British Isles. Thus in 1931

${ }^{23}$ K. Fields, 'What one cannot remember mistakenly', Oral History, 17 (1989), 44-53; A. Thomson, M. Frisch and P. Hamilton, 'The memory and history debates: some international perspectives', Oral History, 22 (1994), 33-43.

24 A. Jackson, Semi-Detached London: Suburban Development, Life and Transport, 1900-39 (London, 1973); F.M.L. Thompson, The Rise of Suburbia (Leicester, 1982). 
29.9 per cent of the population of the County of London had been born outside the metropolis. In addition, London had by far the largest labour market area of any British city, drawing its daily workforce from an everexpanding zone around the home counties. ${ }^{25}$ Employment opportunities were the main motivation for most people migrating to London in the late 1930s. Although the worst of the depression years were over, economic restructuring of the inter-war years meant that a much wider range of work was available in London's offices and factories than in most other parts of the country. ${ }^{26}$

There was a long tradition of migration from Ireland to London. In the nineteenth century London contained the largest Irish-born community in Britain, ${ }^{27}$ and opportunities for employment meant that the capital was also a prominent destination for second-wave Irish migration following the partition of Ireland in $1922 .{ }^{28}$ Young Irish women were especially attracted to work in London in the 1930s, where employment as nurses, in shops, offices and in new automated factories was widespread. Although the bulk of female migration from Ireland to Britain, and especially London, was of Catholic girls (often from the Irish Republic), there was also a steady stream of Protestant migrants from Northern Ireland. ${ }^{29}$ Thus in 1931 there were 39,229 Irish-born women living in the County of London, forming 1.7 per cent of the total female population. Of these 12.4 per cent had migrated from Northern Ireland, though their religious affiliation is not known. ${ }^{30}$ Such migrants were often following well-established migration paths, with existing Irish support networks for new migrants in London. However, despite these networks movement away from home and Ireland

25 J. Westergaard, 'Journeys to work in the London Region', Town Planning Review, 28 (1957), 37-62; R. Lawton, 'The journey to work in England and Wales: forty years of change', Tidjschrift voor Economische en Sociale Geographie, 44 (1963), 61-9.

${ }^{26}$ Pilgrim Trust, Men without Work (Cambridge, 1938); Barlow Report, Report of the Royal Commission on the Distribution of the Industrial Population (Cmd 6153, HMSO, London, 1940).

27 L.H. Lees, Exiles of Erin: Irish Migrants in Victorian London (Manchester, 1979); C. Pooley, 'Segregation or integration? The residential experience of the Irish in mid-Victorian Britain', in R. Swift and S. Gilley (eds.), The Irish in Britain 1815-1939 (London, 1989), 60-83.

28 B. Walter, 'Time-space patterns of second-wave Irish immigration into British towns', Transactions of the Institute of British Geographers, n.s. 5 (1980), 297-317; B. Walter, 'Tradition and ethnic interaction: second wave Irish settlement in Luton and Bolton', in C. Clarke, D. Ley and C. Peach (eds.), Geography and Ethnic Pluralism (London, 1984), 258-83; P. Travers, '“There was nothing there for me": Irish female emigration 1922-71', in P. O'Sullivan (ed.), The Irish World Wide, vol. IV: Irish Women and Irish Migration (London, 1995), 146-67.

${ }^{29}$ B. Walter, Irish Women in London (London, 1988); B. Walter, 'Gender and recent Irish migration to Britain', in R. King (ed.), Contemporary Irish Migration (Dublin, 1991), 11-20; M. Kells, "I'm myself and nobody else": gender and ethnicity among young middleclass Irish women in London', in O'Sullivan (ed.), The Irish World Wide, vol. IV, 201-34; J. McAuley, 'Under an Orange banner: reflections on the northern Protestant experiences of emigration', in P. O'Sullivan (ed.), The Irish World Wide, vol. V: Religion and Identity (London, 1996), 43-69; M. Lennon, M. McAdam and J. O'Brien, Across the Water: Irish Women's Lives in Britain (London, 1988); S. Lambert, Irish Women in Lancashire 1922-1960: Their Story (Lancaster, 2001).

30 Census of England and Wales, 1931. 
was a severe break and meant a substantial adjustment to new places and people. Such movement must also be set against the complex political relationship that existed between Britain, the Republic of Ireland and Ulster after partition. ${ }^{31}$

The inter-war years saw a significant expansion of female employment in the office sector. Although many supervisors' jobs continued to be male, female secretaries and shorthand typists gradually replaced the army of male clerks that had dominated the office sector in the nineteenth century. However, some women who had been employed during the First World War lost their jobs to men returning from the forces. ${ }^{32}$ Within the hierarchy of office employment the Civil Service was perceived as an attractive option. The various branches of the Civil Service employed large numbers of office workers in London and elsewhere (around 387,000 non-industrial workers in 1939 of whom one quarter were female), and offered a secure career structure with short hours, good working conditions and reasonable rates of pay. The disadvantages of office employment in the Civil Service included the fact that there was a competitive entry examination and the expectation that further qualifications would be gained, a very hierarchical structure with most employment in large anonymous typing pools, restrictions on the employment of married women and lower rates of pay than in some private companies. ${ }^{33}$ The experience of $\mathrm{R}$, migrating from Northern Ireland to London to take employment as a typist in a Civil Service office, was thus typical of many girls who moved to the metropolis from Ireland and other parts of the British Isles in the 1930s.

When she first arrived in London in January $1938 \mathrm{R}$ lodged in an (all female) hostel in Earl's Court (West London), but in February 1939 moved to lodge with a family in Canonbury (North London). Initially she worked in the Inland Revenue office at Turnstile House, High Holborn, but in June 1939 was transferred to the Euston Office in Upper Woburn Place. Her home and workplace largely structured the action space through which she moved (Figs. 1, 2). The life world of $\mathrm{R}$ in London was relatively wide ranging, but also followed a routine that meant that most of her journeys

${ }^{31}$ D. Pringle, One Island, Two Nations? A Political Geographical Analysis of the National Conflict in Ireland (Letchworth, 1985); J. Lee, Ireland 1912-1985: Politics and Society (Cambridge, 1989); J. Bardon, A History of Ulster (Belfast, 1992).

32 G. Anderson, Victorian Clerks (Manchester, 1976); G. Anderson (ed.), The White Blouse Revolution: Female Office Workers since 1870 (Manchester, 1988); G. Braybon and P. Summerfield, Out of the Cage: Women's Experiences of Two World Wars (London, 1987).

33 H. Martindale, Women Servants of the State, 1870-1938. A History of Women in the Civil Service (London, 1938); W. Griffiths, The British Civil Service 1854-1954 (London, 1954); E. Cohen, The Growth of the British Civil Service, 1780-1939 (London, 1965); M. Zimmeck, 'Strategies and stratagems for the employment of women in the British Civil Service, 1919-1939', Historical Journal, 27 (1984), 901-24; T. Davey, "“A cissy job for men, a nice job for girls": women shorthand typists in London, 1900-39', in L. Davidoff and B. Westover (eds.), Our Work, Our Lives, Our Words: Women's History and Women's Work (London, 1986), 124-44; K. Sanderson, "“A pension to look forward to ... ?": women Civil Service clerks in London, 1925-1939', in Davidoff and Westover (eds.), Our Work, Our Lives, 145-60. 


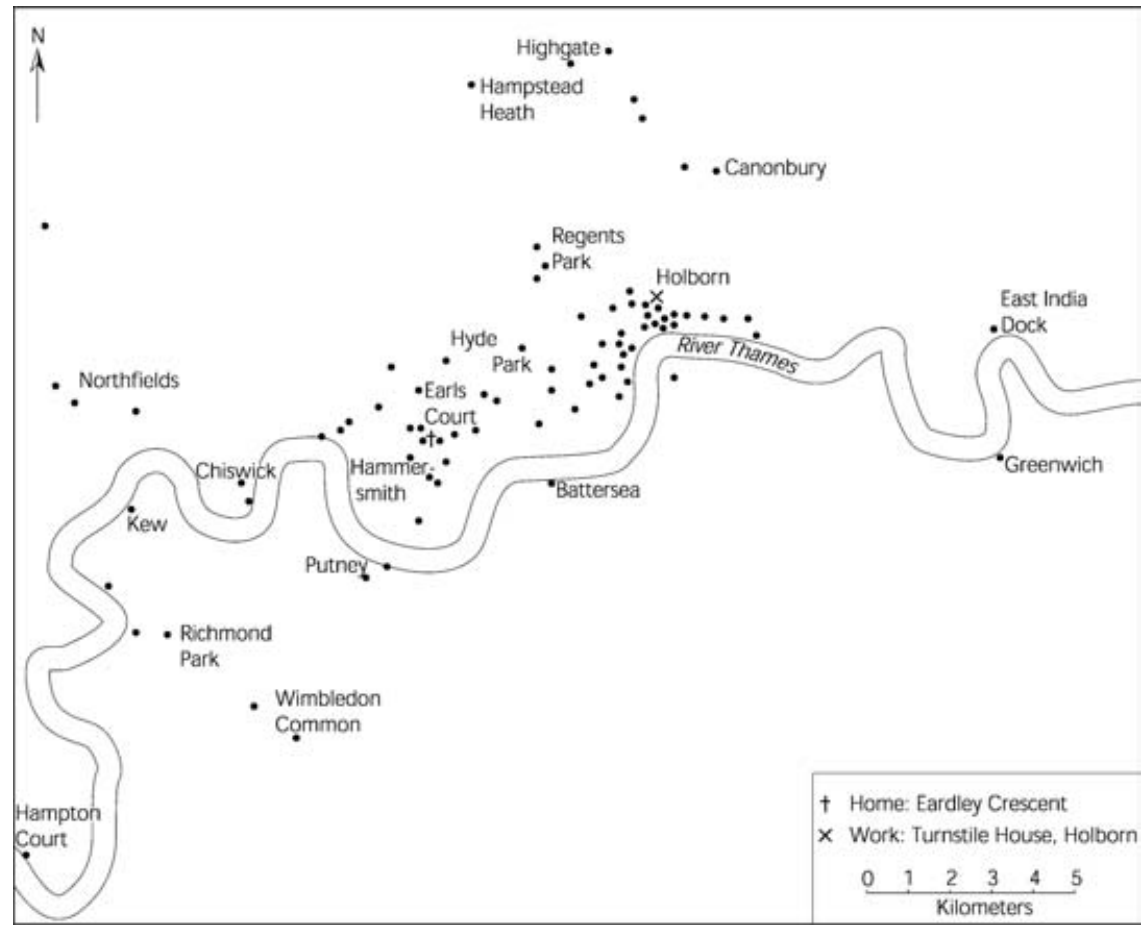

Figure 1: Places in London visited by R whilst living in Earl's Court, January 1938 - February 1939

were through and to familiar places. She walked frequently, used public transport for longer distance travel in the city, rarely felt scared or alienated - though commented on the peculiarities of new locations - and did not mind travelling around London alone, although many of her trips were in the company of friends. The majority of R's daily activities were centred around her home, workplace, central London tourist attractions, cinemas and theatres. Not surprisingly, the location of some of these activities changed when she moved lodgings in February 1939. Thus after moving from Earl's Court to Canonbury, she transferred her evening classes in shorthand typing to a college at Highbury much closer to her new home. She also attended a different church and her regular walks were taken in different parks. However, other activity patterns overlapped and many of the places she visited whilst living in West London continued to be part of her action space when she moved further away. This partly reflects an increasing range of activities and locations because she had been in London longer, but also indicates the importance of certain contacts and activities. Thus she regularly visited a friend in Ealing, and with her went to places such as Kew Gardens and Richmond Park. The ways in which 


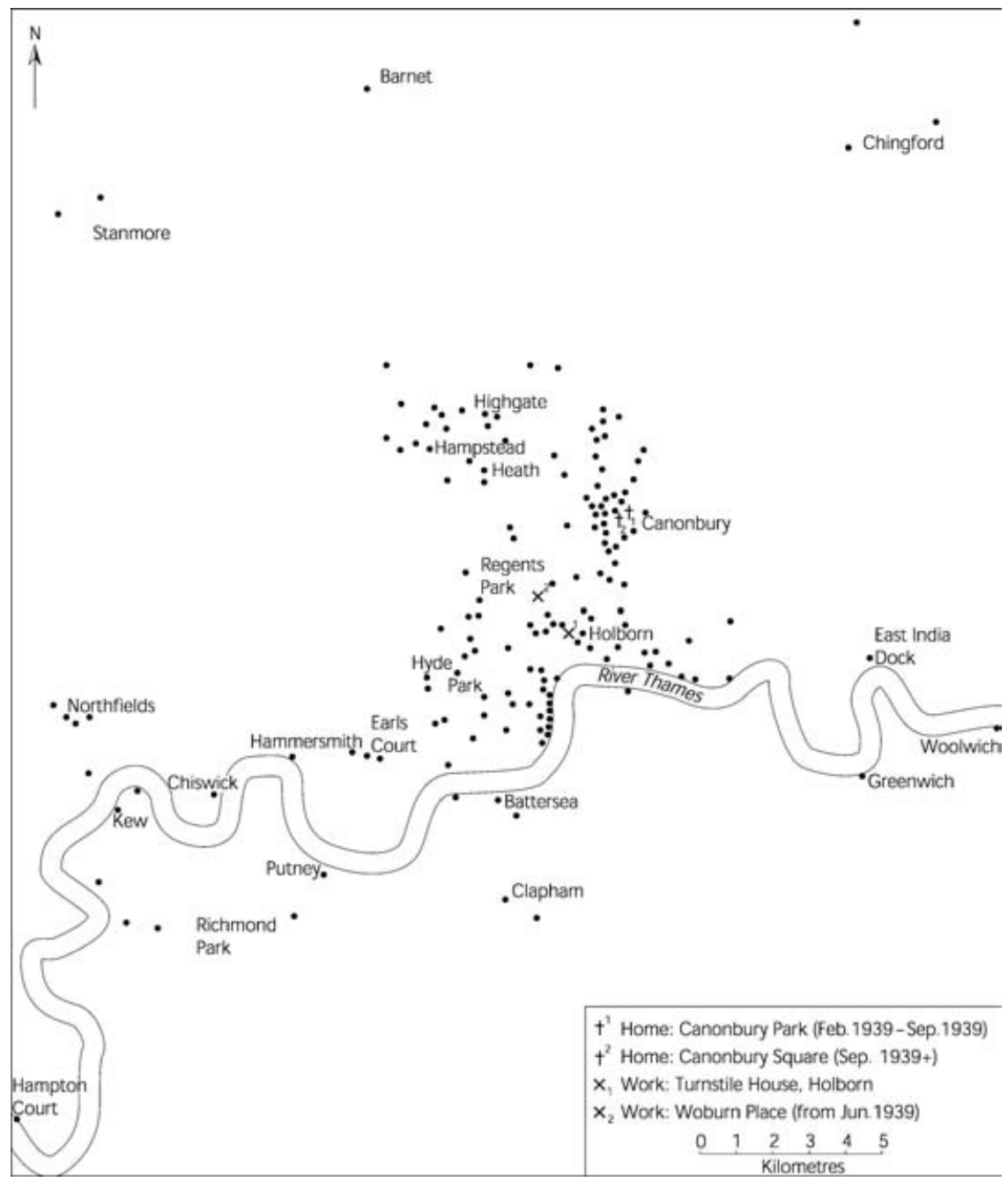

Figure 2: Places in London visited by $\mathrm{R}$ whilst living in Canonbury, February 1939 - December 1940

$\mathrm{R}$ acquired and used spatial knowledge can be illustrated through three examples of her movement around the city during her first few months in London.

\section{Arriving in London}

When she caught the ferry from Belfast to Heysham on 28 January 1938 it was the first time that $R$ had left Ireland. However, she did not travel alone. 
She was accompanied by her father, and by a friend (who was also going to work in London) together with her friend's father. R's father stayed in London over the weekend that she arrived, and they used the time to visit family friends and contacts in and around London, thus apparently giving $\mathrm{R}$ some points of contact in her new environment. However, R's father did not know London either, and in her recollections of the move to London R suggests that they had no firm plans and that they were 'a pair of innocents abroad'. ${ }^{34} \mathrm{R}^{\prime} \mathrm{s}$ diary account of her arrival in London, and first journey to Earl's Court, suggests that she was a keen observer of the environment through which she passed, comparing London to more familiar places, and identifying landmarks that would become part of her spatial knowledge of the city:

We arrived at London at 12.15. It is very bleak looking (the station) and after the style of Belfast station, only bigger. Then we went in a bus to near Earl's Court. When we got off we had a good bit of walking, and my arm ached with holding my things. The road to Earl's Court was very interesting. Full of people, buses, cars and great big shops. ${ }^{35}$

When $\mathrm{R}$ was settled in the hostel, and her father had booked into a nearby guesthouse, $R$ and her father decided to visit a family friend in Ealing (N. London). R's diary account shows that they had difficulty finding the address, and this is backed up by her oral recollections of this first journey across London.

Then Daddy booked his room and we went to N. Ealing. Here we could not find Mayfield Avenue and then found that we had mistaken an W for an N. We walked a bit until we got a bus which took us to near Mayfield Avenue. Mrs S's house is very nice. ${ }^{36}$

We had no plans in a kind of way, no routine to follow. Like we had this tea, in the café, then we decided we would go and see a friend of my father's Mr S. who lived out at Ealing. I remember we got out the address to see what the address was and I don't know how we... I think maybe in the letter it said maybe which station was nearest to where they lived, and I don't think we had a map of London, we were... we didn't know what we were doing did we? I don't think that my father realised how big the place was, and I didn't have the faintest notion. ${ }^{37}$

Both the diary account, and later recollections, suggest that $\mathrm{R}$ (and her father) were relatively unprepared for finding their way around London. They did not use a map, had no clear plans and relied on a relatively wellsigned public transport system to take them to the places they wished to visit. On the Sunday $R$ and her father took the train to Tonbidge in Kent to visit a relative, and on the way back took the opportunity to introduce

\footnotetext{
${ }^{34}$ Interview, 1996.

35 Diary, 29 Jan. 1938.

${ }^{36}$ Ibid.

37 Interview 1996.
} 
$\mathrm{R}$ to some key landmarks in central London: 'Soon after tea we went to the station and came back to London. We walked down the Strand to see Somerset House. I also saw some Fleet Street and Trafalgar Square with Nelson's Monuments. Then we had milk and came home. ${ }^{\prime 38}$ It can be suggested that this was a deliberate strategy to improve R's spatial knowledge of the part of London in which she would be working, and in particular to locate Somerset House where $\mathrm{R}$ was to report for work on Monday morning, though the office to which she was eventually allocated was in High Holborn. It can be suggested that through these mundane spatial practices she began to embed herself in the city, and to acquire sufficient knowledge and cultural capital to enable her to carry out her everyday life.

\section{Establishing a routine in the city}

For her first journey to work on the underground train (about 45 minutes door to door) $\mathrm{R}$ was accompanied by a girl she had met at the hostel, and who also worked for the Inland Revenue. She thus relied on someone with more knowledge of London to get her to work on time: 'I met D. and we went and got our tickets 3/-. We walked through a little green place and up to Somerset House. D. took me to the new wing. ${ }^{\prime 39}$ During her first day at work R's diary records that she found the typing difficult, 'I did more work fearfully slowly and all wrong', and that at lunchtime she had difficulty deciding what to do and where to go. She still found the city disorienting and had not yet acquired sufficient spatial knowledge to use it effectively.

At lunchtime I found that there was no canteen. Some of them got lunch boxes but there was not any left when I went. I didn't know what to do at first and then I went out to a Milk Bar and got soup and hot milk. I then walked about a bit and then went back to the office. ${ }^{40}$

After work she met her father at Charing Cross station and, after tea and a roll in Lyon's Corner House, she caught the tube back to Earl's Court and her father began his journey back to Londonderry. It is significant that they met at Charing Cross which is the station that $\mathrm{R}$ used to get home, rather than Euston which is where her father would have gone to get the train back to Heysham. This suggests that $\mathrm{R}$ was not yet sufficiently confident to find her own way from Euston back to Earl's Court.

However, the following day R's diary records that she was moving around the city with considerably more confidence. She travelled to work alone, making a detailed note of the route, and at lunchtime she had a

\footnotetext{
38 Diary, 30 Jan. 1938.

39 Diary, 31 Jan. 1938.

40 Ibid.
} 
clearer idea of where to go and seemed to begin a deliberate strategy of exploring new places in the vicinity of the office. Overall, after only a day on her own in London, she expressed much more confidence:

After that [breakfast] I went to the station. From there to Charing Cross. I walked through a little park, through Somerset House, across the road, through Bush House, up Aldwych to Kingsway and so to Holborn. Turnstile House is a modern building. I think I can do the things better now. At lunchtime I went to the Milk Bar where I had steak and kidney pie and chips $4^{\mathrm{d}}$. Then I went for a walk and found myself in Lincoln Inns Fields where the solicitors are. I walked round them and saw some men who fed the pigeons and sparrows. ${ }^{41}$

The following day she followed exactly the same routine, but the day after gradually became more adventurous visiting the British Museum in her lunch break and after work met a girl from the hostel and visited Big Ben, the Houses of Parliament and Westminster Abbey. During her first two weeks in London R's routine varied little. She almost always took the same route to work, mostly went to the same Milk Bar for lunch, and then walked round Lincolns Inn Fields and adjacent streets, or visited the British Museum. Some evenings she attended secretarial classes at Bush House after work. She quickly established a restricted action space around her work environment, in which she felt comfortable and which seemed to meet her needs, but she rarely strayed from familiar territory (partly restricted by the length of her lunch break). Similarly, she quickly established a regular routine of activity around her hostel in Earl's Court. She shopped locally (mostly in Woolworths), with other girls from the hostel went to church (St Columba's Church of Scotland), Crusaders (a girls' religious organization) in Holland Park and the cinema in Old Brompton Road. She quickly settled into an ordered existence, moved through familiar territory, often went out with other girls from the hostel, and rarely expressed any feelings of homesickness, fear or unease. She had acquired enough spatial knowledge to feel comfortable and to use the city on a day-to-day basis, and through her everyday mobility and social practices had begun to create her own 'habitus' within the city.

\section{Exploring the city}

Over the next three months R's action space in London gradually extended and she began to make a more deliberate attempt to explore parts of the city that she had not encountered before. In particular, Saturday afternoons and Sundays were increasingly spent on expeditions that took her both to the main tourist sights of central London and further afield. Some of these trips were in the company of other girls from the hostel, some were undertaken to visit friends elsewhere in London or to show visitors around,

${ }^{41}$ Diary, 1 Feb. 1938. 
but others were carried out alone. After a few weeks in the city R appeared to have no fear of travelling quite widely, an interpretation backed up by her recollections: 'I was quite safe. It never crossed my mind that I wasn't safe. ${ }^{42}$

Her first expeditions were mostly with friends from the hostel to view tourist attractions. Thus three weeks after she had arrived in London $\mathrm{R}$ visited Buckingham Palace (of which she gave a detailed description) and then followed a tourist route in which she clearly noted and commented on key landmarks, and was presumably acquiring spatial knowledge for future use:

We went down Constitution Hill (which is not a hill) to Hyde Park Corner. We went down and looked at the 'Duke of Kents' home 3 Belgravia Square. It is not an extra nice house. There was a policeman outside it. After this D and I went down Piccadilly to Piccadilly Circus. On the way I saw fine shops and hotels. I saw Eros in the middle of the Circus. I saw the Mall, the Wellington Memorial and the Duke of York's Monument. We passed through Trafalger Square on our way to Charing Cross station. ${ }^{43}$

On the weekend of 5/6 March she further extended her action space. On Saturday she made her first solo visit to the friend in Ealing that she and her father had called on the first weekend they were in London, and on Sunday she visited Kew Gardens with a friend from the hostel. Other places visited for the first time on outings over the next few weeks included the Victoria and Albert Museum, Regents Park, St Paul's Cathedral, Tottenham Court Road and Oxford Street, Battersea Park and the City of London. In April, R's mother visited from Londonderry and together they toured some of the central tourist sights, and also travelled to Kensington and Hampton Court. Most such journeys were undertaken by tube (though she also used trams or buses and walked quite long distances), details were carefully recorded in the diary, suggesting that $\mathrm{R}$ was building up a personal mental map of the city, and she was clearly increasingly confident in her movement around London. Thus in May she went off on her own to explore a part of London that she had not visited before:

I then decided to do some exploring. I bought a 1/-tram ticket and went off to Hampstead Heath. I arrived at South End Road Gate. There was a Punch and Judy show ... I had a good walk about the Heath. It is very nice but there are far too many people about it. The weather was somewhat cool. I ended out by coming out at the tram terminus at Highgate. I took a trip from there right past the East India Dock. The route there is most interesting and you do see some queer looking people. There is one place I noticed which was very Jewish. It was all not at all like what I thought the East End was. It is very nice indeed in parts... The roadways are all railed in in the East-end and there are only openings for crossings. ${ }^{44}$

42 Interview, 1996.

43 Diary, 19 Feb. 1938.

44 Diary, 8 May 1938. 
This confidence in moving around the city, and R's deliberate desire to explore and acquire spatial knowledge of the city over her first few months in London, is borne out by her later recollections. These also suggest that the clear signing of the underground, and the certainty of moving on a fixed-route transport system, was a real attraction in the first few months when $\mathrm{R}$ was uncertain of how to move from one part of London to another.

During the first year I tended to go on the underground because I, by going on the underground I used to get out at every station in turn and look round and go back, so that in the end I connected up all the places together. Of course London was so big. And after a year or so, then I started to go on the buses. Because then I was able to have a map in my head of what London was. I was able to find my way around. ${ }^{45}$

Not surprisingly she, and her friends, did make mistakes, but they were rarely seen as problematic and were recorded as minor misfortunes to be laughed at. However, they do show that even on the well-signed tube it was possible to make errors that could temporarily disrupt a journey. Thus soon after she arrived in London she recorded: 'When at Charing Cross I took a train which flew past Earl's Court, and away to Hammersmith. Was I astonished! I got a Piccadilly train back, however I was home later than I expected. ${ }^{46}$ And a little later she and her friends again got muddled on the tube in territory with which they should have been fairly familiar. $\mathrm{R}$ recorded the incident in her usual detail.

We decided to take a $1^{\mathrm{d}}$ ride from Holborn to Charing Cross. We went down two escalators, down it seemed into the depths of the earth. We went to platform 4 . We got on a train. We had to change at Leicester Square. We got off alright and went up a couple of escalators. At the top we went to the Baker line. We went down a long escalator. We got on the wrong train. It took us to Warren Road, the opposite direction to Charing Cross. We got off at Warren Road, we tried to get off at Goodge Street but the doors shut before we could get out. We got safely in a train that took us straight to Charing Cross. We got to P just in time for tea at $5 .{ }^{47}$

Overall, evidence from the first four months of R's life in London shows a young woman who, though mostly moving through familiar routes, was also acquiring spatial knowledge that extended over much of the city. There is also evidence, both from the diary and later recollections, that she deliberately attempted to explore unfamiliar parts of the city and that as she built up a clearer mental map of London she moved around with increasing confidence. This sense of being at ease in the city is borne out by both diary entries and later oral testimony. By September 1938 she clearly viewed herself as a Londoner; she had acquired cultural identity with the city, and did not consider returning to the relative safety of Northern

\footnotetext{
45 Interview, 1996.

46 Diary, 7 Feb. 1938.

47 Diary, 27 Feb. 1938.
} 
Ireland in the run up to the Second World War. In this she suggests that she was unusual as many of her friends did leave London and return to their parental homes.

Nearly all the Irish and Scotch girls say that if there is a war they are going home. Did you ever hear of such a cowardly lot! There are, however, a few people like myself who would stay here. ${ }^{48}$

I wonder why all the girls here are simply dying to get home for good? I see only a very few advantages and a whole lot of disadvantages. The chief is, I think, that I would not be able to do exactly as I like. ${ }^{49}$

Oh after a year or so. When the war came I never though of going home. I don't remember anyone at home saying why aren't you coming home... I would have said I was beginning to become a native, yes, I liked London..$^{50}$

\section{Conclusions}

Evidence from one diary, backed up by some later oral testimony, suggests that $R$ developed quite deliberate strategies for acquiring spatial knowledge of London, and very quickly assimilated sufficient information to allow her to operate effectively in the city. Diary evidence also sheds some light on the factors that influenced the acquisition of spatial knowledge. $\mathrm{R}$ took a keen interest in her surroundings and recorded in some detail the places she visited and key landmarks. On her journey to work, to evening classes and for other purposes she travelled along regular routes which, it can be suggested, she negotiated using the buildings and landmarks she recorded in her diary as spatial cues. Thus, following Lynch, ${ }^{51}$ the imageability of London with its distinctive landmarks helped her to navigate the city and enabled her to feel secure when travelling around London.

If landmarks and buildings were important to $R$, maps were not. There is no evidence either from the diary or the oral testimony that she ever owned or used a map to navigate around London when she first arrived. A good 'Geographia' atlas and guide to London was readily available (relatively cheaply at $2 s 6 d$ in the 1940s) but she did not seem to own one. Rather, $\mathrm{R}$ at first relied mainly on the well-signed underground that ran on well-mapped fixed route, later making more use of buses that seemed to require more spatial knowledge to use effectively. Typically, $R$ would identify a station near where she wished to go, use the tube to travel to that station and then (if necessary) ask directions locally to get to her precise destination. The impression is that she found London an easy city to move

\footnotetext{
48 Diary, 14 Sep. 1938.

49 Diary, 15 Sep. 1938.

50 Interview, 1996.

51 Lynch, The Image.
} 
around, using publicly available signs and key landmarks, and without recourse to maps.

$\mathrm{R}$ was not well travelled before she moved to London. Apart from local travel within Northern Ireland (mainly to Belfast and on family holidays) she had rarely been far from home and had certainly not travelled independently. However, this did not seem to curtail her movement within London. Within a few days she acquired sufficient spatial knowledge to move through those parts of the city that she needed to use, and quite rapidly extended this knowledge to new areas. There is no evidence that lack of previous travel experience inhibited the process of getting to know the city.

$\mathrm{R}^{\prime}$ s diary gives the impression that her individual search and exploration strategies were quite deliberate and well organized. After (understandably) feeling somewhat uneasy on her first day alone in London she seemed to develop specific plans that enabled her to get to know the areas in which she lived, worked, shopped and undertook leisure activities. After a few weeks, weekends were increasingly used deliberately to explore new areas of the city. To some extent the ease with which she developed search strategies, despite no previous travel experience, may be related to the fact that she lived with a group of girls in similar circumstances and that many of her early journeys were undertaken in a group. The shared experience of getting to know the city was important and, in her early days in London, there were girls to show her around and familiarize her with the transport system. However, very quickly, R was perfectly happy to explore the city alone and in her determination to stay in London in the run up to war she showed considerable independence.

The acquisition of spatial knowledge by R during her first year in London was almost entirely voluntary. Her journey to work was clearly determined by her employment, but beyond that all her activities were taken to please her. She had few constraints on her life and she seemed very content. Even after the outbreak of war in 1939, her activity pattern changed little. She was forced by bomb damage to move house once (to an adjacent street); some local movements were restricted by air raids, and she increasingly spent more time at weekends staying with a friend outside London to escape the bombing. But for the most part daily activities went on much as before, the main change being that in her role as air raid shelter marshal she mixed rather more with the local community in Canonbury than she had done previously.

In conclusion, it might be asked if any of this is important? The evidence of one diary provides an interesting case study, but can more general conclusions to be drawn? It is suggested that a focus on individual action spaces is important for at least four related reasons.

First, most studies of the social geography of cities continue to focus on the development of residential areas, and the pattern and process of 
residential segregation. ${ }^{52} \mathrm{~A}$ focus on action space emphasizes the fact that in order to understand segregation there is need to focus not only on where people lived, but also on where they worked, shopped, undertook leisure activities or just passed through in their daily lives. ${ }^{53}$ It can be suggested that R's knowledge of the city was rather greater than might be inferred from information on where she lived and worked. The social patterns and processes associated with action spaces rather than residential spaces are rarely studied in the past.

Second, the study of individual action spaces, and the processes by which spatial knowledge is acquired, focuses attention on the ways that residents used the city. It can be suggested that, all too often, the relationship between people and the city is portrayed as relatively passive. ${ }^{54}$ The account in R's diary suggests that she actively used the city as a resource to meet her (often limited) needs. She also developed specific search strategies to gain information, and used this information to structure the activities in her life. There is no reason to suggest that $R$ was in any way unusual in this respect. It can be suggested that more attention should be focused on the role of the spatially active citizen and the ways in which urban space was used in everyday life.

Third, attention is often focused on the role of individual communities in cities, assuming that knowledge of and identity with the local area is particularly important in structuring everyday activities and social relations. ${ }^{55}$ Although some of R's activity patterns were locally based, in reality she (probably like most people) operated in several different communities: the girls with whom she lived; the girls with whom she worked, specific friends that she visited from time to time; church and other social activities. Some of these overlapped, but often they formed separate communities used for different purposes at particular times. A focus on individual knowledge of the city, and the ways in which that knowledge was used through everyday action spaces, reminds us of the complexity of community relations.

Fourth, much contemporary cultural research on urban space and mobility places great emphasis on the cultural significance of place, on issues of identity and alienation and on the role of movement through and use of the city in constructing the self. ${ }^{56}$ Whilst R's diary provides some

52 P. Knox, Urban Social Geography (Harlow, 1995).

53 Eyles, 'Geography of everyday life'; Holloway and Hubbard, People and Place.

54 J. Short, The Urban Order: An Introduction to Cities, Culture and Power (Oxford, 1996); A. Madanipour, 'Urban design and dilemmas of space', Environment and Planning D: Society and Space, 14 (1996), 331-55.

55 T. Haraven, Family and Kin in Urban Communities, 1700-1930 (New York, 1977); D. Page, Communities in the Balance: The Reality of Social Exclusion on Housing Estates (London, 2000).

56 C. Philo (ed.), New Words, New Worlds: Reconceptualising Social and Cultural Geography (Lampeter, 1991); R. Shields, Places on the Margin: Alternative Geographies of Modernity (London, 1991); P. Shurmer-Smith and K. Hannam, Worlds of Desire, Realms of Power (London, 1994); D. Sibley, Geographies of Exclusion (London, 1995). 
evidence of such practices, it also demonstrates the limitations of such general theories of space, place and identity. Re-creation of R's first few months in London from her diary creates a picture of a 19-year-old girl adopting a very pragmatic approach to establishing herself in a new urban environment. Most of her journeys were undertaken either for routine and material reasons (work, study, shopping), or were deliberately constructed to explore the city. R moved easily through a substantial part of London, and she quickly established her identity as a Londoner. However, there is little evidence that she strongly identified with particular places or communities. It can be suggested that for $\mathrm{R}$ the construction of self and place identity occurred at a very general level: identification with the totality of a large, complex and exciting city, rather than with particular aspects of the urban environment.

In historical research it is relatively rare to gain access to sources that provide sufficient detail to reconstruct the minutiae of everyday life. Even oral evidence is suspect as many mundane events may be distorted. A detailed diary is the only way in which such material is likely to survive. It is thus proposed that this case study, which certainly cannot claim any typicality, does suggest some more general points. As outlined above these emphasize the complexity and individuality of spatial search strategies and the acquisition of spatial knowledge about a city. However, it also needs to be emphasized that whilst knowledge of a city is essential to allow residents to use its resources effectively, for some the size, complexity and relative anonymity of the city is also an advantage. This was clearly stated by $\mathrm{R}$ who not only got to know London well, but also on reflection valued the protective anonymity that it provided, particularly in relation to what she saw as the more claustrophobic small-town community of Londonderry:

What I like about London and all this is the fact that you are anonymous. Nobody knows you. At first I thought it was a disadvantage didn't I, people not knowing you. After a while I've discovered it was a marvellous thing. The fact that nobody knew you and that you were free. You were free to do whatever you liked. Get whatever you liked. Go wherever you liked. That is marvellous, isn't it! ${ }^{57}$

Her knowledge that London was anonymous, and the lack of identity (and identification) that it conveyed, was another important part of the information she gained during her early years in the capital. 